\title{
EFFECT OF NATURAL TOTAL GLYCOALKALOIDS IN DISCARDED POTATO TUBERS AND VINES ON MILK YIELD AND RUMEN ENVERONMENTAL IN DAIRY ZARIBI GOATS . Saleh, M.R.M. \\ Animal Production Research Institute, Agricultural ResearchCenter, Dokki, Egypt .
}

\begin{abstract}
This work aimed to study the residual of total glycolalkaloids (TGA) in discarded, trophy and greenish spots of tubers and vines as a natural toxic components and their effects on milk yield, milk composition and rumen activities of lactating Zaribi goats fed potato tuber and vine on the form of silage or hay. Twenty four lactating Zaribi goats with an average body weight of $41.76 \mathrm{~kg}$ and aged 30-36 months. Animals were divided into three similar groups (8 animals in each) were assigned randomly to receive one of 3 experimental rations. Animals were fed concentrate feed mixture(CFM)to cover $50 \%$ of requirements according to NRC(1990). The experimental diets were $50 \%$ concentrate feed mixture(CFM) $+50 \%$ experimental materials as well as berseem hay as control $\left(G_{1}\right)$,potato tuber and vine silage(PTVS)or potato vine hay(PVH)in second and third rations $\left(\mathrm{G}_{2}\right.$ \& $\mathrm{G}_{3}$ ),respectively. The experiment lasted for 120 days. Nutrient digestibility's and nutritive value were determined. Data obtained for TGA values were significantly $(p<0.05)$ higher for potato vines hay $(P V H)$ in (diets, milk, feces and urines) than potato tubers and vines silage (PTVS).Moreover minerals in experimental rations as well as macro-elements(Calcium, Phosphor ,Magnesium, Sodium, Potassium) and micro-elements(Copper, Zinc, Manganese and Iron) of $\mathrm{G}_{3}$ was significantly $(p<0.05)$ lower among all tested treatments, whereas the excretion of same elements in feces and urine of $\mathrm{G}_{3}$ ration were significantly $(p<0.05)$ higher than the $G_{2}$ values. On the other hand PTVS $\left(G_{2}\right)$ had higher quality of all tested parameters as well as $\mathrm{pH}$, ammonia, lactic acid and total volatile fatty acid (TVFA's).Subsequent daily DM intake of dairy goats as $\% \mathrm{BW}$ or $\mathrm{g} / \mathrm{kg} \mathrm{w} \mathrm{w}^{0.75}$ decreased with $\mathrm{G}_{1}$ (3.58 and 90.99) and $\mathrm{G}_{2}$ (3.62 and 91.91)respectively, compared with $\mathrm{G}_{3}$ (3.69 and 93.73). At same time,the feed intake tended to increase with $G_{1}$ and $G_{3}$ groups and the values were(61.3:38.7\&61.7:38.3)respectively compared with $\mathrm{G}_{2}$ ration(60.9 :38.1).Data of hematology clearly that values of white blood cells count (haematocrit, AST, ALT, urea, creatinine and bilirubin)were significantly $(P<0.05)$ higher of $G_{3}$ group compared to $G_{1}$ and $G_{2}$ groups. Moreover, Milk yield of dairy goats was significantly $(P<0.05)$ lower with $G_{3}(1.376 \mathrm{~kg} / \mathrm{h} / \mathrm{d})$ than $\mathrm{G}_{1}(1.451 \mathrm{~kg} / \mathrm{h} / \mathrm{d})$ and $\mathrm{G}_{2}(1.417$ $\mathrm{kg} / \mathrm{h} / \mathrm{d}$ ) respectively. The CP of digestibility was significantly increased with ration containing PTVS and control.While the difference of CP digestibility between $\mathrm{G}_{1}$ and $\mathrm{G}_{3}$ rations were about $10 \%$. Addition to NDF, ADF, Hemicellulose ,cellulose and ADL digestibility coefficients of $G_{3}$ ration were significantly $(p<0.05)$ lower compared to the other tested rations. This may be due to the high concentration of $A D L$ in $G_{3}$ and $G_{1}$ rations .Cell wall constituent(CWC)as NDF, ADF, ADL, celluloses and hemicelluloses recorded higher significant $(p<0.05)$ for $G_{1}$ and $G_{2}$ rations than $G_{3}$. The higher values of acetate, Butrate , Iso-Butyrate were recorded with $\mathrm{G}_{3}$. Ammonia- $\mathrm{N}$ and TVFA's in rumen liquor were higher with $G_{2}$ followed by $G_{3}$ and $G_{1}$ through different sampling times.The total bacterial count, cellulytic bacteria and protozoa were recorded significantly higher $(p<0.05)$ with $\mathrm{G}_{2}$ at 0,3 and $6 \mathrm{hrs}$ post-feeding.
\end{abstract}

Keywords:Total glycoalkaloids (TGA)residue, Milk yield and constituents, mineral, goats rumen, 


\section{INTRODUTION}

The population of ruminant animals in Egypt was predicated to be as 9.3 million animal units in year 2008. This animals required about 15.6 million tons of TDN and 2.345 million tons of DCP (Abdelhamid et al.,2001).The available conventional feed resources could cover only $84 \%$ and $89 \%$ of the required TDN and DCP, respectively(Abou Akkada,1984).This shortage of the concentrate feed in Egypt is a well-known problem. Therefore, several studies were carried out to improve the nutritive values of the poor quality roughages to overcome the feed shortage problem and the dramatic increase in prices of animal feed ingredients. Low fecal excretions of minerals as calcium, magnesium, phosphorus, and sulfur resulted in positive balances for these minerals. Abdelhamid et al.,(1999 a\& b)reported that blood minerals of dairy Zariby goats contained 8.13-8.29 mg Ca/dl,3.45-4.31 mg P/ dl,2.69 $3.63 \mathrm{mg} / \mathrm{dl}$ and $60.8-96.2 \mu \mathrm{g} \mathrm{Fe} / \mathrm{dl}$. On the other side the National Toxicology Program suggests that the average American consumers must be not receive more than $12.5 \mathrm{mg} /$ person/day of total glycoalkaloids(TGA) of greenish spots and trophy potatoes.So up to date there are a few literature on using discarded and trophy potatoes residues in animal feeding .Therefor, there is a need for more studies on using these fields by-products in animal feeding. However, feeding common greenish potato led to TGA toxicity and affected performance of starter, growing and finishing ruminants (Patil et al.,1972) and (Jadhav et al.,1981)found natural occurring toxic alkaloids in potatoes byproducts.(Morris and Lee,1984)and(Renwick et al.1984)reported TGA causing emberyotoxicity and teratogenicity, also it was inhibition of rat cholinesterase isoenzymes in vitro and in vivo by the potato alkaloid.(Alozie et al.,1978) found that toxic dose of TGA from $0.01-0.1 \%$ of potato on DM bases.

\section{MATERIALS AND METHODS}

The present study was carried out at El-Serw Animal Production Research Station, Animal Production Research Institute, Agricultural Resech Research Center, Cairo, Egypt .

\section{Experimental animals}

Twenty four dairy Zaribi goats were used in this study having average live body weight of $41.76 \mathrm{~kg}$ and about 30 moths of age. All goats were healthy. The goats were divided randomly into three similar groups(eight animals each) according to body weight. Each group was housed in separate closed pen and kept under shade and all groups received the same management under the same conditions.Animals were weighed at the begining and at biweekly intervals thereafter. The experimental lasted for120 days.

Feeding and management

All animals were fed concentrate feed mixture(CFM)to cover $50 \%$ of requirements recommended by $\mathrm{NRC}(1990)$.In addition to $50 \%$ of one as following berseem hay as control $\left(G_{1}\right)$, potato tuber and vine silage(PTVS) or potato vine hay $(P V H)$ in second $\left(G_{2} \& G_{3}\right)$ and third rations 
respectively.Raton's were offered twice daily at 8 am and $4 \mathrm{pm}$, water was available all times and measured daily as average for each group. Sample of feeds were analyzed according to the procedures of A.O.A.C.(2000).Nutrient digestibility.

\section{Silage preparation}

Greenish spots, discarded, trophy and greenish spots tubers in addition to some smaller infirmity and fresh aerial parts were chopped manually using knives, then wilted by spreading under direct sun for a day then mixed with wheat straw : fresh potato tubers and vine at ratio of(4:1 ratio on DM bases)then supplemented with 5\% molasses and 3\% urea and ensiled in white plastic bags for 2 months before feeding. After ensilage, the color and odor of the silage were examined and samples were taken for chemical analysis, total glycoalkaloids (TGA) was determined and silage quality test was performed then the silage was stored in closed room .

\section{Milk yield and milk samples}

Individual morning and evening milk yield of lactating dairy Zaribi goats were recorded daily. Milk samples (about $0.5 \%$ of total milk produced) were taken once biweekly from each goat.Then the samples were mixed and analyzed for total solid(T.S),fat, solid nonfat (SNF)and ash. Milk fat, lactose and protein, while milk was calculated by difference. And TGA was qualitative determination.

\section{Blood samples}

Blood samples were collected from the jugular vein once before feeding ( 3 animals from each group).It collected into tubes with anticoagulant for determination of the total Neutrophil, Lymphocyte, Monocyte and Eosinophil on blood film stained with wrights stain(Coles,1986). The red and white blood cells were determined(Miller and Weller1971)in whole blood. Blood samples were centrifuged at $4000 \mathrm{rpm}$ for 20 minutes. Part of the separated serum was used to enzymes activity determination, while the other part was stored frozen at-20c 0 till the biochemical analysis.Commercial kits were used for colorimetric biochemical determinations.

\section{Rumen liquor and microorganisms}

Rumen fluid samples were taken from 3 animals of each experim-ental group using stomach tube before feeding ( 0 time)and 3 and 6 hrs post-feeding.The samples were filtered through3 layers of gauze and immediately subjected to the determination of $\mathrm{pH}$ value using $\mathrm{pH}$ meter. Ammonia nitrogen(NH3-N)concentration was determined according to Conway (1957),total volatile fatty acids(TVFA) was determined according to Warner (1964) and Erwin et al.,(1961).Direct microscopic counts of bacteria was determined according to Warner(1964), while microbial protein was determined according to Schultz and Schultz(1970). Enumeration of cellulolytic bacteria was determined according to Mann (1968).Total protozoa count were determined according to Abou-Akkada et al.,(1969).

\section{Feces and urine collection}

At end of the experiment three animals from each group were chosen and put in metabolic cages for, feces and urine collection daily for seven successive days after two weeks preliminary period. Urine was measured daily and collected after diluted with $20 \mathrm{ml}$ of conc. sulfuric acid to 
preserve ammonia until nitrogen determination. Whereas TGA was determination quantitivly in PTVS , PVH, feces and urine. On the other hand feed intake was recorded daily.

\section{Analytical methods}

Analysis of feed ingredients and feces were carried out according to A.O.A.C.(2000) for DM, OM ,CP and EE. Plasma biochemical analysis was done using reagent kits.TGA was determined according to Carman et al. (1984) and Bushway and Ponnampalam (1985). Milk fat (MF), total protein (TP), total solid(TS), solid nonfat(SNF)and ash according to Ling(1963). Total protein was determined according to Weichselbaum (1989), albumin was determined according to Doumas et al., (1971), urea according to Patton and Crouch(1977),liver enzymes was determined according to Reitman and Frankle(1957),total cholesterol was determined according to Monnet(1963), creatinine according to Bartiles(1971), bilirubin was determined according to Elveback (1970).Whereas hemoglobin and haematocrit was determined according to Linne and Ringsrud (1992), red and white blood cells was determined according to Miller and Weller (1971).

\section{Statistical analysis}

Data was statistically analyzed using SAS(2003).When F-test was positive, least significant differences was determined according to Duncan (1955).

\section{RESULTS AND DISCUSSION}

\section{Composition of ingredients and experimental rations}

Data in Table(1)showed the analysis of feed ingredients and experimental diets. $C P$ was significantly higher( $p>0.05)$ with $G_{1}$ and $G_{2}$ rations. These results are consistent with those obtained by Abdelhamid et al.,(1992) reported that there were variations in the chemical composition of different agriculture wastes .CF,EE and NFE of $\mathrm{G}_{2}$ ration was significantly $(p<0.05)$ higher than the other experimental rations. The increasing of TGA level in PVH is very danger indication because its accumulation in body and act as over load on kidney and liver and finally lead to ecumenical loss or death of animals. These results agreement with (Gull et al .1970 and Dalvi and Bowie 1983), reported that TGA is a toxic in greenish spots of Solanum $\underline{s p}$, it defects the protein digestibility and growth performance .

\section{Total glycoalkaloids (TGA)}

TGA residues was determined for $G_{1}, G_{2}$ and $G_{3}$ rations as well as feces, urine and milk Table(2), and data obtained showed clearly that $G_{1}$ ration free of TGA, whereas $\mathrm{G}_{3}$ was significantly $(P<0.05)$ higher for both ration, milk , urine and feces than those of $G_{2}$. These data are in agreement with those of Alozie et al.,(1978)who reported that there inhibition of cholinesterase isoenzymes in vitro and in vivo of TGA, whereas Anon(1988) reported that TGA is a poison associated with a school lunch program while Dalvi and Bowie(1983) reported that TGA is toxic and it inhibit protein digestibility and growth performance. Additional Hansen(1985) found two fatal cases of greenish spots potato are poisoning. On the other hand Chabue and 
Swinyard(1976) found that TGA is teratogenicity and toxicological phenolic compound with solunum tuberOsum (ST).

Table (1) : Chemical composition of ingredients and experimental rations fed by dairy Zaribi goats ( $\%$ on dry matter basis).

\begin{tabular}{|l|c|c|c|c|c|c|}
\hline \multicolumn{1}{|c|}{ Items } & OM & CP & CF & EE & ASH & NFE \\
\hline \multicolumn{7}{|c|}{ Ingredients } \\
\hline CFM $^{*}$ & 89.70 & 14.88 & 13.40 & 3.10 & 10.30 & 58.92 \\
\hline $\mathrm{B} \mathrm{H}^{* *}$ & 88.58 & 14.16 & 25.14 & 2.59 & 11.42 & 46.69 \\
\hline PTVS $^{* * *}$ & 86.23 & 13.08 & 14.20 & 3.48 & 13.77 & 56.47 \\
\hline PVH $^{* * *}$ & 88.49 & 11.89 & $17.59^{*}$ & 2.86 & 11.51 & 56.19 \\
\hline & 89.22 & $13.94^{\mathrm{A}}$ & $14.09^{\mathrm{B}}$ & $2.85^{\mathrm{B}}$ & $10.78^{\mathrm{A}}$ & $58.34^{\mathrm{B}}$ \\
\hline $\mathrm{G}_{1}$ & 90.24 & $13.30^{\mathrm{A}}$ & $11.48^{\mathrm{C}}$ & $3.96^{\mathrm{A}}$ & $9.76^{\mathrm{B}}$ & $61.50^{\mathrm{A}}$ \\
\hline $\mathrm{G}_{2}$ & 89.57 & $11.59^{\mathrm{A}}$ & $17.55^{\mathrm{A}}$ & $2.76^{\mathrm{B}}$ & $10.43^{\mathrm{A}}$ & $57.67^{\mathrm{B}}$ \\
\hline $\mathrm{G}_{3}$ & & & & & & \\
\hline
\end{tabular}

Means with different superscripts within the same column are significantly different at ( $\mathrm{P}<0.05)$.

${ }^{*}$ Concentrate feed mixture (CFM) is consists of cotton seed $16.5 \%$, yellow corn $41.50 \%$ wheat bran $25 \%$, soy

been meal (44\% CP) $7.0 \%$, molasses $5.00 \%, 3 \%$ Urea, common salt $0.5 \%$ and limestone $1.50 \%$.

${ }^{* *}(\mathrm{BH})=$ Berseem hay ${ }^{* * *}(\mathrm{PTVS})=$ Potato tubers and vines silage ${ }^{* * *}(\mathrm{PVH})=$ Potato vines hay 
Table (2): TGA contents of diets, feces, urine and milk of dairy Zaribi goats fed experimental rations.

\begin{tabular}{|l|c|c|c|}
\hline \multirow{2}{*}{ Items } & \multicolumn{3}{c|}{ TGA consumed , mg / h / d } \\
\cline { 2 - 4 } & $\mathbf{G}_{1}$ & $\mathbf{G}_{2}$ & $\mathbf{G}_{3}$ \\
\hline rations & - & $133.88^{\mathrm{B}}$ & $382.51^{\mathrm{A}}$ \\
\hline Feces & - & $39.80^{\mathrm{B}}$ & $71.93^{\mathrm{A}}$ \\
\hline Urine & - & $28.47^{\mathrm{B}}$ & $58.21^{\mathrm{A}}$ \\
\hline Milk & - & $29.37^{\mathrm{B}}$ & $72.63^{\mathrm{A}}$ \\
\hline
\end{tabular}

Means with different superscripts within the same row are significantly different at $P<0.05)$.

Silage quality

Data in Table(3) indicated that $\mathrm{G}_{2}$ silage had higher quality of all tested parameters including $\mathrm{pH}$, ammonia ,lactic acid and TVFA's. These results were inagreement with those reported by Abou-Akkada and Nour (1986), since ensilage can preserve feed and improve its feeding value.

Table (3): Mean values of different quality parameters of potato silage.

\begin{tabular}{|l|c|}
\hline \multicolumn{1}{|c|}{ Items } & $\mathbf{G}_{2}$ \\
\hline PH value & 4.69 \\
\hline Ammonia- N ( mg/100g ) & 24.75 \\
\hline Lactic acid(mg/100g ) & 2.31 \\
\hline TVFA's ( ME q/100g ) & 22.10 \\
\hline Ammonia \% of DM & 7.12 \\
\hline Lactic acid \% of DM & 0.76 \\
\hline
\end{tabular}

Feed and water consumption

Daily DM intake of dairy goats are presented in Table (4). The total 
Table(4) : Body weight gain, DM Intake and Daily Feed intake of Zaribi goats Fed on tested Experimental Rations.

\begin{tabular}{|c|c|c|c|}
\hline Items & $\mathbf{G}_{1}$ & $\mathbf{G}_{1}$ & $\mathbf{G}_{1}$ \\
\hline Average BWG ( KG ) & \multicolumn{3}{|c|}{41.76} \\
\hline \multicolumn{4}{|l|}{ DM intake $(\mathrm{gm} / \mathrm{d} / \mathrm{h})$} \\
\hline CFM & 585 & 585 & 590 \\
\hline $\mathrm{BH}$ & 925 & - & - \\
\hline PTVS & - & 910 & - \\
\hline $\mathrm{PVH}$ & - & - & 950 \\
\hline Total DM intake $(\mathrm{gm} / \mathrm{d} / \mathrm{h})$ & $1510^{A}$ & $1495^{\mathrm{B}}$ & $1540^{A}$ \\
\hline DM intake, \% BW & 3.62 & 3.58 & 3.69 \\
\hline DM intake, $\mathrm{g} / \mathrm{kgw}^{0.75}$ & $91.91^{\mathrm{A}}$ & $90.99^{\mathrm{B}}$ & $93.73^{\mathrm{A}}$ \\
\hline $\begin{array}{l}\text { Roughage:concentrate(R/C) } \\
\text { ratio }\end{array}$ & $61.3: 38.7$ & 60.9:38.1 & $61.7: 38.3$ \\
\hline \multicolumn{4}{|l|}{ Daily water consumption } \\
\hline $\mathrm{L} / \mathrm{h} / \mathrm{d}$ & 3.67 & 3.32 & 3.96 \\
\hline $\mathrm{Ml} / \mathrm{kg} \mathrm{BW}$ & $88^{\mathrm{A}}$ & $80^{\mathrm{B}}$ & $95^{\mathrm{A}}$ \\
\hline $\mathrm{Ml} / \mathrm{kg} \mathrm{W}^{0.82}$ & $234^{\mathrm{A}}$ & $202^{\mathrm{B}}$ & $241^{\mathrm{A}}$ \\
\hline Ml/g DM intake & $2.43^{\mathrm{A}}$ & $2.23^{\mathrm{B}}$ & $2.57^{A}$ \\
\hline
\end{tabular}

Means with different superscripts within the same row are significantly different at ( $\mathbf{P}<0.05)$.

DM intake as \% BW or $\mathrm{g} / \mathrm{kg} \mathrm{w}$ w $^{0.75}$ was decreased with $\mathrm{G}_{2}(3,62$ and 91.91) and $\mathrm{G}_{1}$ ( 3.62 and 90.99),compared with $\mathrm{G}_{3}$ (3.69 and 93.73) respectively. In the same time,the ratio of roughage to concentrate tended to increase with both $\mathrm{G} 1$ and $\mathrm{G}_{3}\left(61.3: 38.7\right.$ and 61.7:38.3)respectively, than $\mathrm{G}_{2}$ ration(60.9: 38.1).Generally, the increased roughages intake as well as berseem hay(BH),PTVS and PTVH gave positive evidence for silage of good quality and Ensiling improved feeding value with lactating goats, that as reported by Abou Akkada and Nour(1986).Whereas the data of average daily water consumption showed that there higher significantly differences $(p<0.05)$ with $G_{1}$ and $G_{3}$ than $G_{2}$, whereas no significant differences were noticed between $\mathrm{G}_{1}$ and $\mathrm{G}_{3}$. 


\section{Blood picture}

Data in Table (5) indicated that blood of animals fed $\mathrm{G}_{2}$ ration showed significantly higher $(\mathrm{P}<0.05)$ total protein, albumin and glucose concentrations than does given $G_{1}$ and $G_{3}$ rations. The high concentration of total blood proteins in group $2\left(\mathrm{G}_{2}\right)$ may be due to increase synthesis of protein from urea supplement during silage making, Harinder et al., (2008). Also they recorded that chemical composition proved that tubers and vines silage are good source of protein(13.8\%) and carbohydrates (60.0\%)when supplemented to ration instead of berseem hay.On the other side data obtained showed that there higher significant differences $(p>0.05)$ of blood ketones, APT,AST,GGT,LDH,WBC,RBC,Hb,hematocrite and percentage of PCV between all tested treatments. Blood biochemical determination revealed that reductions of $G_{1}$ and $G_{2}$ in total protein, albumin and glucose concentrations Compared to $\mathrm{G}_{3}$ ration. Rich blood biochemical may be due to the utilization proteins as a result of urea supplement. Also, great level of glucose in blood was related to altitude carbohydrates.TGA have an enhancement effect on red and white blood cells Azim et al.,(1984).they reported that high glycoalkaloid feeding caused negative effects on red blood cell counts and hemoglobin concentr-ation. Pollman and Danielson(1980) reported that PVH was high of TGA and it caused increased in haematocrite, AST,ALT, urea,creatinine and bilirubin. Moreover the other blood constitutes (RBC,Hemoglobin,Total protein and Total cholesterol)significantly $(p<0.05$ ) higher for both $G_{1}$ and $G_{2}$ than $G_{3}$. In addition to data of white blood fractions showed significant $(p<0.05)$ decrease in erythrocyte and leucocytes for $G_{3}$ compared with $G_{2}$ and $G_{1}$. On the other side the fractions of white blood cells(neutrophile and lymphocyte\%)and eiosinophile were significantly higher $(p<0.05)$ and the monocyte was significantly lower for $G_{3}$.This increases of lymphocyte and neutrophil for $\mathrm{G}_{3}$ may be due to the increases of TGA level and the decreases the of protein compared to other tested group . beside that the TGA have an enhancement effect to the humeral immune response and increase white blood cells as reported by Saleh et al.,(2009). 
Table (5): Blood parameters and hematological picture of lactating Zaribi Goats affected by experimental rations.

\begin{tabular}{|c|c|c|c|}
\hline Blood parameters & G1 & G2 & G3 \\
\hline WBC (x103/L) & $9.43^{\mathrm{A}}$ & $9.26^{\mathrm{B}}$ & $10.07^{\mathrm{A}}$ \\
\hline RBC (x106/L) & $11.29^{A}$ & $10.98^{\mathrm{A}}$ & $9.57^{\mathrm{B}}$ \\
\hline PCV (\%) & $31.37^{\mathrm{B}}$ & $30.61^{\mathrm{B}}$ & $34.26^{A}$ \\
\hline $\mathrm{Hb}(\mathrm{g} / \mathrm{dl})$ & 10.30 & 10.70 & 9.83 \\
\hline Hematocrit (\%) & $21.50^{B}$ & $25.50^{B}$ & $33.20^{\mathrm{A}}$ \\
\hline Total protein $(\mathrm{g} / 100 \mathrm{~g})$ & $8.60^{A}$ & $8.30^{A}$ & $6.77^{\mathrm{B}}$ \\
\hline Albumen $(\mathrm{g} / 100 \mathrm{~g})$ & $3.86^{\mathrm{A}}$ & $3.92^{\mathrm{A}}$ & $3.03^{\mathrm{B}}$ \\
\hline Globulin (g/100 g) & $4.74^{\mathrm{A}}$ & $4.38^{A}$ & $3.74^{\mathrm{B}}$ \\
\hline BTKB / mmol/l & 9.63 & 9.88 & 9.46 \\
\hline Creatinine $\mathrm{mmol} / \mathrm{l}$ & $75.25^{\mathrm{A}}$ & $61.39^{\mathrm{B}}$ & $88.39^{A}$ \\
\hline $\mathrm{AP}(\mathrm{U} / \mathrm{L})$ & 54.81 & $58.39 \mathrm{~B}$ & 57.51 \\
\hline$\overline{\mathrm{AST}}(\mu / \mathrm{ml})$ & $44.0 \mathrm{~B}^{\mathrm{C}}$ & $38.00^{\mathrm{C}}$ & $76.00^{A}$ \\
\hline $\operatorname{ALT}(\mu / \mathrm{ml})$ & $27.0 \mathrm{~B}^{\mathrm{B}}$ & $20.00^{B}$ & $40.00^{\mathrm{A}}$ \\
\hline GGT (U/L) & $62.48^{\mathrm{A}}$ & $54.48^{\mathrm{A}}$ & $48.83^{A}$ \\
\hline $\mathrm{LDH}(\mathrm{U} / \mathrm{L})$ & $248.22^{\mathrm{A}}$ & $218.96^{\mathrm{B}}$ & $202.37^{\mathrm{B}}$ \\
\hline Glucose(mg/dl) & $47.73^{A}$ & $55.82^{\mathrm{A}}$ & $48.62^{\mathrm{B}}$ \\
\hline Totalcholesterol (mg/100ml) & $144.4^{A}$ & $128.0^{A}$ & $109.0^{\mathrm{B}}$ \\
\hline Urea (mg/100ml) & $18.30^{\mathrm{B}}$ & $21.90^{B}$ & $33.60^{\mathrm{A}}$ \\
\hline Creatinine $(\mathrm{mg} / 100 \mathrm{ml})$ & $0.80^{\mathrm{B}}$ & $0.74^{\mathrm{B}}$ & $1.30^{\mathrm{A}}$ \\
\hline Bilirubin (mg /100ml) & $0.40^{\mathrm{B}}$ & $0.39^{B}$ & $0.60^{\mathrm{A}}$ \\
\hline Lymphocyte (\%) & $55.8^{\mathrm{B}}$ & $57.3^{B}$ & $63.7^{A}$ \\
\hline Neutrophile (\%) & $42.5^{\mathrm{B}}$ & $41.8^{\mathrm{B}}$ & $57.9^{\mathrm{A}}$ \\
\hline RBCs $\left(10^{6}\right.$ ul ) & $10.04^{\mathrm{A}}$ & $10.77^{\mathrm{A}}$ & $8.58^{\mathrm{B}}$ \\
\hline Eiosinophile (\% ) & $5.20^{A}$ & $4.70^{\mathrm{B}}$ & $6.90^{\mathrm{A}}$ \\
\hline
\end{tabular}

Means with different superscripts within the same row are significantly different at $\mathrm{P}<0.05)$. 


\section{Milk production and composition}

Table(6) : Showed average milk yield and its constituents of Zaribi goats given the different experimental diets. The differences in milk yield were significant $(P<0.05)$ among the tested the experimental rations. The daily milk yield had the highest values with $\mathrm{G}_{2}(174 \mathrm{~kg}$ over the experimental period followed by $\mathrm{G}_{1}$ (170 $\mathrm{kg}$ lover the experimental period ) and the lowest value was recorded with $\mathrm{G}_{3}$ ration (164 $\mathrm{kg}$ over the experimental period). This results in agreement with those obtained by (Polman and Danielson, 1980 , Saleh et al ., 2007\& 2008)reported that TGA have an enhancement effect on the humoralimmune response.Milk yield,fat,total protein(TP),total solid(TS), and solid not fat (SNF)of $G_{1}$ and $G_{2}$ were significantly $(P<0.05)$ higher than $G_{3}$ group.These improvements of milk yield and composition in $\mathrm{G}_{2}$ was correlated with the high OM,CP and NFE and lower $\mathrm{CF}$ and ash than $\mathrm{G}_{1}$ and $\mathrm{G}_{3}$.(Table1). These improvements were correlated with low level of TGA in $\mathrm{G}_{2}$ (Table 2).

Table ( 6 ) : Effect of tested rations on milk yield and its constituents of Zaribi goats.

\begin{tabular}{|c|c|c|c|}
\hline Item & G1 & G2 & G3 \\
\hline Total milk yield, $\mathrm{kg} / \mathrm{h}$ & $170^{\mathrm{A}}$ & $174^{\mathrm{A}}$ & $164^{\mathrm{B}}$ \\
\hline Average milk yield, $\mathrm{kg} / \mathrm{h} / \mathrm{d}$ & $1.417^{\mathrm{A}}$ & $1.451^{\mathrm{A}}$ & $1.367^{\mathrm{B}}$ \\
\hline \multicolumn{4}{|c|}{ Milk composition: } \\
\hline Fat, \% & 3.71 & 3.89 & 3.37 \\
\hline Protein, $\%$ & 3.06 & 3.24 & 2.87 \\
\hline Lactose, $\%$ & 4.73 & 4.96 & 4.47 \\
\hline Total solids, $\%$ & 12.18 & 12.53 & 11.82 \\
\hline Solids non fat (SNF), \% & $8.47^{\mathrm{A}}$ & $8.64^{\mathrm{A}}$ & $7.95^{\mathrm{B}}$ \\
\hline Ash, $\%$ & $0.84^{\mathrm{A}}$ & $0.89 \mathrm{~A}$ & $0.77^{\mathrm{B}}$ \\
\hline Average fat yield, $\mathrm{g} / \mathrm{h} / \mathrm{d}$ & $526^{A}$ & $564^{\mathrm{A}}$ & $461^{\mathrm{B}}$ \\
\hline Average protein yield, $\mathrm{g} / \mathrm{h} / \mathrm{d}$ & $434^{\mathrm{A}}$ & $470^{\mathrm{A}}$ & $392^{B}$ \\
\hline
\end{tabular}




\section{Minerals utilization}

Data of minerals obtained are presented in Table(7).Minerals intake of $\mathrm{G} 3$ had recorded higher differences among treatments, than those in $\mathrm{G}_{1}$ and $\mathrm{G}_{3}$. These results back to decrease of TGA level in $\mathrm{G}_{2}$ ration. While minerals excretion of $\mathrm{G}_{3}$ (feces and urine) were recorded higher variation differences for calcium and phosphorus excretion than those obtained from $G_{2}$ and $\mathrm{G}_{1}$. These results agreed with(Hoek et al.,1988) they reported that TGA affecting on magnesium, calcium and phosphorus excretion and relationship between Calcium: phosphorus ratio.

Table(7): Minerals metabolism by dairy Zaribi goats fed experimental rations.

\begin{tabular}{|c|c|c|c|c|c|}
\hline Element & Rations & Intake & Feces & Urine & Retention \\
\hline \multicolumn{6}{|c|}{ Macro - minerals ( mg / h / d ) } \\
\hline \multirow[t]{3}{*}{ Calcium } & $\mathrm{G}_{1}$ & $4833^{\mathrm{B}}$ & $978^{\mathrm{B}}$ & $228^{B}$ & $3627^{B}$ \\
\hline & $\mathrm{G}_{2}$ & $5672^{\mathrm{A}}$ & $1173^{\mathrm{A}}$ & $295^{\mathrm{A}}$ & $4204^{\mathrm{A}}$ \\
\hline & $\mathrm{G}_{3}$ & $4511^{\mathrm{B}}$ & $953^{B}$ & $247^{\mathrm{B}}$ & $3311^{\mathrm{C}}$ \\
\hline \multirow[t]{3}{*}{ Phosphorus } & $\mathrm{G}_{1}$ & $3158^{B}$ & $896^{A}$ & $215^{\mathrm{B}}$ & $2047^{B}$ \\
\hline & $\mathrm{G}_{2}$ & $3814^{\mathrm{A}}$ & $763^{B}$ & 198 & $2853^{A}$ \\
\hline & $\mathrm{G}_{3}$ & $2958^{B}$ & $714^{\mathrm{B}}$ & 194 & $2050^{\mathrm{B}}$ \\
\hline \multirow[t]{3}{*}{ Magnesium } & $\mathrm{G}_{1}$ & $3412^{\mathrm{B}}$ & $717^{\mathrm{B}}$ & 197 & $2498^{B}$ \\
\hline & $\mathrm{G}_{2}$ & $4026^{A}$ & $845^{A}$ & 206 & $2975^{\mathrm{B}}$ \\
\hline & $\mathrm{G}_{3}$ & $3659^{C}$ & $826^{A}$ & 235 & $2579^{B}$ \\
\hline \multirow[t]{3}{*}{ Sodium } & $\mathrm{G}_{1}$ & $5487^{B}$ & $1183^{B}$ & $308^{\mathrm{A}}$ & $3996^{\mathrm{B}}$ \\
\hline & $\mathrm{G}_{2}$ & $6618^{A}$ & $1341^{\mathrm{A}}$ & $347^{\mathrm{A}}$ & $4930^{A}$ \\
\hline & $\mathrm{G}_{3}$ & $4394^{C}$ & $922^{\mathrm{C}}$ & $233^{\mathrm{B}}$ & $3239^{C}$ \\
\hline \multirow{3}{*}{ Potassium } & $\mathrm{G}_{1}$ & $328^{C}$ & $68^{\mathrm{B}}$ & 22 & $238^{C}$ \\
\hline & $\mathrm{G}_{2}$ & $498^{B}$ & $105^{\mathrm{A}}$ & 29 & $364^{\mathrm{B}}$ \\
\hline & $\mathrm{G}_{3}$ & $548^{\mathrm{A}}$ & $112^{\mathrm{A}}$ & 33 & $403^{A}$ \\
\hline & \multicolumn{5}{|c|}{ Micro - minerals $(\mathrm{mg} / \mathrm{h} / \mathrm{d})$} \\
\hline \multirow[t]{3}{*}{ Copper } & $\mathrm{G}_{1}$ & $23.76^{\mathrm{C}}$ & 4.98 & 1.75 & 17.03 \\
\hline & $\mathrm{G}_{2}$ & $58.32^{\mathrm{A}}$ & 11.75 & 3.92 & 42.65 \\
\hline & $\mathrm{G}_{3}$ & $46.93^{\mathrm{B}}$ & 9.64 & 2.46 & 34.83 \\
\hline \multirow[t]{3}{*}{ Zinc } & $\mathrm{G}_{1}$ & $158.44^{\mathrm{B}}$ & 37.13 & 12.75 & 108.56 \\
\hline & $\mathrm{G}_{2}$ & $242.67^{A}$ & 49.31 & 17.70 & 175.66 \\
\hline & $\mathrm{G}_{3}$ & $184.26^{\mathrm{C}}$ & 37.20 & 21.60 & 125.46 \\
\hline \multirow[t]{3}{*}{ Manganese } & $\mathrm{G}_{1}$ & $640.32^{B}$ & 132.15 & 34.47 & 473.70 \\
\hline & $\mathrm{G}_{2}$ & $911.20^{\mathrm{A}}$ & 316.80 & 38.40 & 556.00 \\
\hline & $\mathrm{G}_{3}$ & $531.60^{C}$ & 134.10 & 19.30 & 378.20 \\
\hline \multirow[t]{3}{*}{ Iron } & $\mathrm{G}_{1}$ & $238.40^{C}$ & 604.20 & 150.00 & 1626.4 \\
\hline & $\mathrm{G}_{2}$ & $3015.2^{\mathrm{A}}$ & 605.40 & 150.80 & 2259.00 \\
\hline & $\mathrm{G}_{3}$ & $2869.7^{\mathrm{B}}$ & 562.80 & 141.30 & 2306.90 \\
\hline
\end{tabular}

Means with different superscripts within the same column are significantly different at ( $\mathrm{P}<0.05)$.

\section{Digestion coefficients and nutritive values}

Nutrient digestibility coefficients and nutritive values of the experimental rations are presented in Table (8).Dry matter (DM) and organic matter(OM) digestibility of $G_{1}$ and $G_{3}$ rations were significantly $(p<0.05)$ lowerer than those of $G_{2}$ ration. On the other side $G_{2}$ ration data showed the highest digestibility 
coefficient of $D M, O M, C F$ and $E E$ and significantly $(p<0.05)$ lower of $E E$ and NFE than those of $G_{1}$ and $G_{3}$. The apparent digestibility of $C P$ significantly increased with ration containing PVS and control groups. The different between the control group $\left(\mathrm{G}_{1}\right)$ and $\mathrm{PVH}\left(\mathrm{G}_{3}\right)$ in $\mathrm{CP}$ digestibility was about $10 \%$.Subsequen $E E$ digestibility was similar for $G_{1}$ and $G_{2}$ rations being significantly $(p<0.05)$ lower with $G_{3}$ ration. The present results are in agreement with those reported by Robb et al.,(1994) they found almost similar results to that obtained here. NDF, ADF, hemicellulose, cellulose and ADL digestibility coefficients significantly decreased with ration containing high level of TGA $\left(\mathrm{G}_{3}\right)$ compared to the other tested rations. This depression in digestibility coefficient could be due to the decrease in ruminal fiber digestion that may occur with increasing level of ADF contents in $G_{3}$ and $G_{1}$ compared to the $G_{2}$ ration which resulted in an increase in rate of passage of digest from the rumen Bull et al.,(1979).Also TDN and DCP of $\mathrm{G}_{3}$ was significantly $(p<0.05)$ lower is affected by the high level of total glycoalkaloids compared with $G_{1}$ and $G_{2}$ groups. No differences were notice of TDN and DCP between $G_{1}$ and $G_{2}$ groups, the values of TDN were( 67.3 and 10.3),(69.4 and 10.8)and (61.2 and 9.49)for $\mathrm{G}_{1}, \mathrm{G}_{2}$ and $\mathrm{G}_{3}$,respectively. These results are in agreement with Schmeider and Flatt (1975);Abd El-Baki et al.,(1997).Metabolizable energy values was higher in PTVS compared with $\mathrm{G}_{1}$ and $\mathrm{PVH}$, and the values were 3179, 3044 and $2985 \mathrm{kcal} / \mathrm{kg}$ for, $\mathrm{G}_{2}, \mathrm{G}_{1}$ and $G_{3}$, respectively. This agree with Fekete,(1987).Who reported that potato silage was high in metabolisable energy.

Table (8) : Nutrient digestibility coefficients and feeding values of Experimental rations fed by dairy Zaribi goats fed.

\begin{tabular}{|c|c|c|c|}
\hline Items & G1 & G2 & G3 \\
\hline DM & $72.3^{\mathrm{A}}$ & $73.4^{\mathrm{A}}$ & $70.6^{\mathrm{B}}$ \\
\hline $\mathrm{OM}$ & $70.5^{\mathrm{B}}$ & $74.2^{\mathrm{A}}$ & $68.7^{\mathrm{B}}$ \\
\hline $\mathrm{CP}$ & $67.2^{\mathrm{B}}$ & $71.6^{A}$ & $64.6^{C}$ \\
\hline $\mathrm{CF}$ & $69.3^{A}$ & $70.6^{\mathrm{B}}$ & $65.1^{\mathrm{C}}$ \\
\hline EE & $66.4^{\mathrm{B}}$ & $63.2^{\mathrm{C}}$ & $69.5^{A}$ \\
\hline NFE & $70.2^{\mathrm{A}}$ & $68.5^{\mathrm{A}}$ & $62.8^{\mathrm{B}}$ \\
\hline \multicolumn{4}{|c|}{ Fiber fraction digestability , \% } \\
\hline NDF & $62.18^{\mathrm{A}}$ & $57.55^{\mathrm{B}}$ & $65.92^{\mathrm{A}}$ \\
\hline ADF & $59.53^{\mathrm{A}}$ & $53.55^{\mathrm{B}}$ & $61.88^{\mathrm{A}}$ \\
\hline Hemcellulose & $69.18^{\mathrm{A}}$ & $60.75^{\mathrm{B}}$ & $67.73^{\mathrm{A}}$ \\
\hline cellulose & $70.59^{A}$ & $62.18^{\mathrm{B}}$ & $67.18^{\mathrm{A}}$ \\
\hline ADL & $\mathrm{A}$ & $28.14^{\mathrm{B}}$ & $32.90^{\mathrm{A}}$ \\
\hline \multicolumn{4}{|c|}{ Nutritive value , \% } \\
\hline TDN & $67.3^{A}$ & $69.4^{\mathrm{A}}$ & $61.2^{\mathrm{B}}$ \\
\hline DCP & $9.37^{A}$ & $9.52^{\mathrm{A}}$ & $7.49^{\mathrm{B}}$ \\
\hline \begin{tabular}{|l} 
ME kcal / kg diet \\
\end{tabular} & $3081^{\mathrm{A}}$ & $3242^{A}$ & $2986^{\mathrm{B}}$ \\
\hline
\end{tabular}

Means with different superscripts within the same row are significantly different at ( $P<0.05)$. 


\section{Cell wall constituents (CWC) of the experimental diets}

The means of cell wall constituents of experimental diets are presented in Table (9). $G_{2}$ had the lowest contents of neutral detergent fiber (NDF),acid detergent fiber (ADF), acid detergent lignin (ADL), hemicelluloses and cellulose than other experimental rations. These results agree with those of Azim et al.,(1983)who found that greenish spots of potato contained $60.6 \%$ cell wall constituents(CWC),ADF $54.9 \%$,hemicelluloses $5.7 \%$, ADL $37.7 \%$ and cellulose $10.6 \%$. These results are more than those obtained here .

Rumen liquor parameters

Data of liquor as well as $\mathrm{pH}$ values, ammonia- $\mathrm{N}$ levels, and total volatile fatty acids(TVFA's)concentration of rumen liquor of the experimental animals are presented in Table(10)there were significant differences among sampling time $(p<0.05)$ among dietary treatments for all tested parameters. Although NH3-N concentration gradually decreased by sampling time till the 6 hrs, the $\mathrm{pH}$ values decreased only till the $3 \mathrm{hrs}$, but on the opposite,TVFA's level gradually increased till $3 \mathrm{hrs}$ post-feeding. The normal relation of rumen parameters were realized, since there were positive relation between $\mathrm{pH}$ value and NH3-N concentration and negative relations with TVFA's levels.Since consuming NH3-N by ruminal micro-flora producing TVFA's leading to lowering $\mathrm{pH}$ values. $\mathrm{G}_{2}$ group produced the lowest $\mathrm{pH}$ in compared to others. These results of overall $\mathrm{pH}$ were in harmony with those obtained by Khalifa (1972) who noticed that $\mathrm{pH}$ of rumen liquor with sheep was high(7.1) before feeding then declined to (6.8) at $3 \mathrm{hrs}$.

Table ( 9 ) : Cell wall constituents (CWC) of the experimental diets( on DM basis ).

\begin{tabular}{|l|c|c|c|}
\hline Items & $\mathbf{G}_{1}$ & $\mathbf{G}_{\mathbf{2}}$ & $\mathbf{G}_{3}$ \\
\hline NDF & $44.77^{\mathrm{A}}$ & $31.21^{\mathrm{C}}$ & $38.07^{\mathrm{B}}$ \\
\hline $\mathrm{ADF}$ & $32.94^{\mathrm{A}}$ & $24.94^{\mathrm{C}}$ & $29.21^{\mathrm{B}}$ \\
\hline $\mathrm{ADL}$ & $10.26^{\mathrm{A}}$ & $7.10^{\mathrm{B}}$ & $9.34^{\mathrm{B}}$ \\
\hline Hemicellulose & $11.83^{\mathrm{A}}$ & $6.27^{\mathrm{B}}$ & $8.86^{\mathrm{C}}$ \\
\hline cellulose & $22.68^{\mathrm{A}}$ & $17.84^{\mathrm{B}}$ & $19.87^{\mathrm{A}}$ \\
\hline
\end{tabular}

Means with different superscripts within the same row are significantly different at ( $P<0.05)$.

Table(10): Rumen liquor parameters of lactating Zaribi goats fed on experimental rations.

\begin{tabular}{|l|c|c|c|c|}
\hline Item & Time & $\mathbf{G}_{1}$ & $\mathbf{G}_{\mathbf{2}}$ & $\mathbf{G}_{\mathbf{3}}$ \\
\hline \multirow{3}{*}{$\mathrm{pH}$} & 0 & $6.87^{\mathrm{A}}$ & $6.15^{\mathrm{B}}$ & $6.92^{\mathrm{A}}$ \\
\cline { 2 - 5 } & 3 & $6.64^{\mathrm{A}}$ & $6.02^{\mathrm{B}}$ & $6.51^{\mathrm{A}}$ \\
\cline { 2 - 5 } & 6 & $6.56^{\mathrm{A}}$ & $6.07^{\mathrm{B}}$ & $6.43^{\mathrm{A}}$ \\
\hline \multirow{3}{*}{ Ammonia -N mg / $100 \mathrm{ml}$} & 0 & $14.58^{\mathrm{B}}$ & $22.21^{\mathrm{A}}$ & $16.46^{\mathrm{B}}$ \\
\cline { 2 - 5 } & 3 & $16.94^{\mathrm{B}}$ & $25.04^{\mathrm{A}}$ & $19.33^{\mathrm{B}}$ \\
\cline { 2 - 5 } & 6 & $13.67^{\mathrm{B}}$ & $21.18^{\mathrm{A}}$ & $14.85^{\mathrm{A}}$ \\
\hline \multirow{3}{*}{ TVFA's meq / $100 \mathrm{ml}$} & 0 & $8.24^{\mathrm{B}}$ & $12.56^{\mathrm{A}}$ & $7.85^{\mathrm{B}}$ \\
\cline { 2 - 5 } & 3 & $13.87^{\mathrm{B}}$ & $17.67^{\mathrm{A}}$ & $13.53^{\mathrm{B}}$ \\
\cline { 2 - 5 } & 6 & $10.51^{\mathrm{B}}$ & $14.24^{\mathrm{A}}$ & $9.15^{\mathrm{B}}$ \\
\hline
\end{tabular}

Means with different superscripts within the same row are significantly different at ( $\mathbf{P}<0.05)$. 
Molar proportion of ruminal volatile fatty acid (TVFA's)

Differences between acetic, propionate, butyrate and Iso-butyrate values of rumen liquor of lactating Zaribi goats fed Potato silage or hay shown in Table (11).Data clear that there significant $(p<0.05)$ decrease in acetic, butyrate and iso-biotrate and increase of propionate and valerate of G3 , compared to control and G2. Acetic :propionate(A/P) ratio indicated an improvement of propionic production in $\mathrm{G} 2$, while it recorded highest value with G3.The results obtained were confirmed those represented by Mohammed et al ,(2003).

Table(11). Molar proportion of ruminal volatile fatty acid (TVFA's) of lactating Zaribi goats fed on experimental rations .

\begin{tabular}{|l|c|c|c|}
\hline Item & $\mathbf{G}_{1}$ & $\mathbf{G}_{\mathbf{2}}$ & $\mathbf{G}_{3}$ \\
\hline Acetate $\%$ & $39.86^{\mathrm{A}}$ & $35.55^{\mathrm{C}}$ & $37.33^{\mathrm{B}}$ \\
\hline Propionate $\%$ & $27.84^{\mathrm{B}}$ & $34.51^{\mathrm{A}}$ & $22.85^{\mathrm{C}}$ \\
\hline Acetate:Propionate \% & $1.43: 1$ & $1.03: 1$ & $1.63: 1$ \\
\hline Butyrate, \% & $19.57^{\mathrm{B}}$ & $17.21^{\mathrm{C}}$ & $21.84^{\mathrm{A}}$ \\
\hline Iso - butyrate \% & $2.68^{\mathrm{A}}$ & $1.67^{\mathrm{B}}$ & $2.91^{\mathrm{A}}$ \\
\hline Valerate, \% & $1.76^{\mathrm{B}}$ & $2.49^{\mathrm{A}}$ & $1.37^{\mathrm{B}}$ \\
\hline
\end{tabular}

Means with different superscripts within the same row are significantly different at ( $\mathrm{P}<0.05)$.

\section{Rumen microorgani}

Ration containing tuber and vine silage has a great effect in terms of increased the total viable bacterial count in rumen $(P<0.05)$ compared with $G 1$ and G3(Table12).Bacterial counts were significantly higher $(p<0.05)$ for $G 2$ group before feeding , 3 and 6 hrs post-feeding and the values being 1860, 2617 and $4346 \times 10^{7} / \mathrm{ml}$. These values were higher than other tested treatments. The results obtained are in harmony with those of Kurihara et al.,(1998) they observed that the peak of bacterial counts was between 3 and $6 \mathrm{hrs}$ after feeding .

Moreover, the results of total cellulolytic bacterial count showed that the highest values of total cellulolytic bacterial obtained at $3 \mathrm{hrs}$ after feeding for $\mathrm{G} 2$, but the lowest value was recorded with $G 3$ and $G_{1}$. In this respect, Behraka et al.,(1991)reported that rumen have a large and more active bacterial population, it may help to increase the rate of digestion.In the other studies,Nour et al.,(1989) found that feeding animals on concentrate with roughages increased the total protozoal count in the rumen .

The results of total protozoal count recorded the highest values at 3 hrspost-feeding with $\mathrm{G} 2$ ration compared with other experimental treatments. 
While the lowest values were recorded with $G_{3}$ ration . This may be back to the high level of TGA in $\mathrm{G}_{3}$ ration. These results were in Harmony with those obtained by Sony and Sharma(1982)who found an increased in ciliate protozoa count $(p<0.05)$ with increasing concentrate and silage level in diets. This possibly may be related to its ability to ingest starch,the maximum protozoal counts were observed at $3 \mathrm{hrs}$ post-feeding than immediately before feeding.

Table (12) . Effect of experimental rations fed by lactating Zaribi goats on Rumen microorganisms

\begin{tabular}{|c|c|c|c|c|}
\hline \multicolumn{1}{|c|}{ Items } & Time & $\mathbf{G}_{1}$ & $\mathbf{G}_{2}$ & $\mathbf{G}_{3}$ \\
\hline & 0 & $1519^{\mathrm{B}}$ & $1860^{\mathrm{A}}$ & $1347^{\mathrm{C}}$ \\
\hline Total bacterial count $\left(10^{7} / \mathrm{ml}\right)$ & 3 & $2175^{\mathrm{B}}$ & $2617^{\mathrm{A}}$ & $2080^{\mathrm{C}}$ \\
\hline & 6 & $3818^{\mathrm{B}}$ & $4346^{\mathrm{A}}$ & $3576^{\mathrm{C}}$ \\
\hline Cellullolytic bacterial $\left(10^{4} / \mathrm{ml}\right)$ & 3 & $4.68^{\mathrm{A}}$ & $5.57^{\mathrm{A}}$ & $3.91^{\mathrm{B}}$ \\
\hline & 6 & $3.72^{\mathrm{B}}$ & $4.65^{\mathrm{A}}$ & $2.64^{\mathrm{C}}$ \\
\hline & 0 & $3.97^{\mathrm{B}}$ & $4.61^{\mathrm{A}}$ & $3.88^{\mathrm{B}}$ \\
\hline Total protozoal count $\left(10^{4} / / \mathrm{ml}\right.$ & 3 & $3.41^{\mathrm{B}}$ & $4.79^{\mathrm{A}}$ & $3.52^{\mathrm{B}}$ \\
\hline & 6 & $2.97^{\mathrm{B}}$ & $4.27^{\mathrm{A}}$ & $3.11^{\mathrm{B}}$ \\
\hline
\end{tabular}

Means with different superscripts within the same row are significantly different at $\mathrm{P}<0.05$ ).

\section{Feed conversion and economical efficiency}

Data of average feed intake and average milk yield during experimental period as well as feed conversion efficiency of the dairy Zaraibi goats are summarized in Table (13). The data indicated that average milk

yield recorded the highest value with $\mathrm{G}_{2}(1.451 \mathrm{~kg} / \mathrm{h} / \mathrm{d})$ followed by $\mathrm{G}_{1}(1.417$ $\mathrm{kg} / \mathrm{h} / \mathrm{d})$ and lastly,the lowest value $(1.376 \mathrm{~kg} / \mathrm{h} / \mathrm{d})$ with $\mathrm{G}_{3}$.Thus, the feed conversion calculated as DM and CP intake/kg milk yield , and the data obtained show that silage have a better values $(1.03$ and 0.324 , of DM and CP respectively) and $G_{1}$ was (1.07and 0.306 respectively)compared with $G_{3}$ (1.13 and 0.317 , respectively).Whereas water consumption showed significantly $(P<0.05)$ higher values with $G_{2}$ than the $G 1$ and $G_{3}$ groups the values were $(3760, \quad 3320$ and $3960 \mathrm{ml} / \mathrm{h} / \mathrm{d})$ for $\mathrm{G}_{1}, \quad \mathrm{G}_{2}$ and $\mathrm{G}_{3}$,respectively.Water consum-ption positively correlated with $\mathrm{DM}$ intake, CF and ash content (Table1) and TGA content (Table 2).These results were in agreement with the results obtained in other study Sultan (1995).Moreover , the study shown that use of $50 \%$ tubers and vines in the form of silage or 
hay in small ruminant nutrition recorded increase of economic efficiency(E.E) with significant $(\mathrm{P}<0.05)$ higher for control group compared to PTVS and PVH rations, the values were $1.86,2.88$ and 2.62 LE for control , PTVS and PVH respectively. Subsequent the economic revenue \% were 0, 55 and $40 \%$ of total coast .These decreases in feed cost of $\mathrm{G}_{2}$ and $\mathrm{G}_{3}$ is related to that tuber and vine as silage or hay are cheaper by products. These data are in agree with Murdoch(1992), who reported that cost of animal feed decreased when potato by-products used in lactating animals rations .

Table (13) : Feed conversion and economical efficiency of lactating Zaribi does fed experimental rations.

\begin{tabular}{|c|c|c|c|}
\hline Item & $\mathbf{G}_{1}$ & $\mathbf{G}_{2}$ & $\mathbf{G}_{3}$ \\
\hline Average body weight, kg & 42.14 & 41.48 & 41.66 \\
\hline Metabolic body size, w 0.75 & 16.54 & 16.34 & 16.40 \\
\hline CFM, g/h/d & 585 & 585 & 590 \\
\hline Rpughages, g/h/d & 925 & 910 & 950 \\
\hline Total DM intake, $\mathrm{g} / \mathrm{h} / \mathrm{d}$ & 1510 & 1495 & 1540 \\
\hline CP intake, g/h/d & 210.5 & 183.9 & 178.5 \\
\hline TDN intake, $\mathrm{kg} / \mathrm{h} / \mathrm{d}$ & 2.16 & 2.03 & 2.34 \\
\hline TDN kg /kg milk & 1.52 & 1.40 & 1.71 \\
\hline DCP intake, $\mathrm{kg} / \mathrm{h} / \mathrm{d}$ & 0.61 & 0.60 & 0.58 \\
\hline DCP/ kg milk & 13.49 & 14.92 & 12.53 \\
\hline Daily water consumption L/h/d & 3.67 & 3.32 & 3.96 \\
\hline Average milk yield, g/h/d & 1417 & 1451 & 1367 \\
\hline \multicolumn{4}{|c|}{ Feed conversion } \\
\hline Kg DM / kg milk & 1.07 & 1.03 & 1.13 \\
\hline Kg CP / kg milk & 0.149 & 0.127 & 0.130 \\
\hline \multicolumn{4}{|l|}{ Daily feed cost (LE) } \\
\hline Price of daily MILK (LE) & 4.25 & 4.35 & 4.10 \\
\hline Feed cost (LE) kg milk & $2.39^{\mathrm{A}}$ & $1.47^{\mathrm{B}}$ & $1.48^{B}$ \\
\hline Economic efficiency ( E.E.) & 1.86 & 2.88 & 2.62 \\
\hline Improved of E.E.\% & - & 55 & 41 \\
\hline
\end{tabular}

\section{CONCLUSIONS}

In conclusion, greenish, discarded and trophy potatoes tubers and vines in the form of silage could be used safety,successfully and economically in ration of lactating Zaribi goats. It is recommended therefor to fed tubers and vines as silage and not in the form of hay, because the feeding tubers and vines on the form of silage( PTVS) could decrease feeding cost and increase feed efficiently. 


\section{REFERENCES}

Abd El-Baki,S.M; A.A.Zaki ;S.M.Bassuny,and K.M.EIGendy,(1997).Nutritional studies on some green forages in Egypt.J.Nutr.Feeds,1(special Issue): 133-143.

Abdelhamid,A.M.; M.S.Nowar and S.M.Bassuny(2001).Evaluation of uncoventional silage making using plant and animal wastes in feeding ruminants.J.Agric.SCI.MansouraUniv.,26:5349-5360.

Abd El hamid, M. A ; E.I .Shehata and M.E . Ahmed ( 1999 a) .Physio nutritional studies on pregnant and lactating goats fed on rations deffering in roughage/ concentrate ratio2 -Effect on blood profile .J.Agric. Sci. Mansoura Univ.,24 : 4587- 4597.

Abd El hamid, M.A;E.I Shehata and M.E.Ahmed(1999 b).Physio - nutritional studies on pregnant and lactating goats fed on rations deffering in roughage / concentrate rati3-Effect on productivity and digestion . J.Agric. Sci.Mansoura Univ.,24:4598 -4612.

Abdelhamid,A.M.; S.A.El-youty; T.H.Topps; M.M.El-Shinnawy ;A.A.Gabr,and H.H.El-sadany(1992).Evaluation of some untraditional and conventional and feeds in Dakahlia governorate.Arch.Anim.Nutr.,42:371- 381.

Abou-Akkada, A.R.(1984).Evaluation of present status and potential development of animal feed resources in the Arab countries AC Khartom, p.129

Abou Akkada, A.R. and A. M. Nour (1986 ). ensilage and improvement of feeding value. Alexandria, Septamber, p . 40 .

Abou Akkada, A.R. ; E.E. Bartley and L.R. Fina ( 1969 ) . Ciliate protozoa in the rumen of the lactating cow. J. Dairy Science , $7: 1088-1091$.

Alozie,S.O.; R.P.Sharma and D.K.Salunkhe (1978).Inhibition of rat cholinesterase isoenzymes in vitro and in vivo by the potato glycoalkalloid,(alpha-solanine and alpha caconine).J.Food Biochem.,2:259- 276.

Anon B.R.(1988).Solanine food poisoning associated with a school lunch.J. Agric . Food Chem., 483 - 490.

A.O.A.C.(2000).Association of Official Analytical Chemists of Official Methods of Analysis17 ed. Washington D.C.

Azim,A.,Shaikh,H.A.and Ahmed,R. (1983).Toxic effects of high glycoalkaloid feeding on the protein digestibility and growth of the rabbits.J.Pharm. Univ.Karachi.,2:15-24.

Azim,A.;H.A.Shaikh and R.M.Ahmed(1984).Toxic effects of high glycoalkaloid feeding on the red blood cell counts and haemoglobin concentration of rabbit blood. J.Pharm. Univ. Karachi, 3: 43 - 49.

Bartiles,H.(1971).Calorimetric determination of creatinine.Clin.Acta.32- 81.

Behraka, A.A.;T.G.Nagaraja and J.L.Morrill(1991).Performance and ruminal function development of young rumenants fed diet with TGA fermentation extract. J. Dairy Scie ., $74: 432-4336$.

Bull,L.S.;W.V.Rumpler;T.F.Sweaney and R.A.Zinn(1979).Influnce of rumenal turnover on site and extent of digesion Fed. Proc. 38: 2713-2719. 
Bushway,R.J. and R.Ponnampalam(1985).alpha-solanine content of potato products.J.Agric.Food Chem., 34:277-279.

Carman,A.S.; S.S.Kuan and O.J Francis.(1984).Determination of the potato glycoalkaloids J.Agric .Food Chem., 66:582-586.

Chaube,S. and C.A.Swinyard (1976). Teratological and toxicologicalstudies of alkaloidal and phenolic compounds from Solanum tuberosumL .Toxicol . Appl .Pharmacol.,36:227-237.

Coles , E.H.( 1986 ). Vetrinary Clinical Pathology . W.B.Saunders Company , Philadeliphia . USA.

Conway, E.F.(1957). Micro diffusion Analysis and Volumetric Error. Rev. Ed. Lock Wood, London.

Dalvi,R.R.and W.C.Bowie (1983).Toxicology of solanine: an overview.Vet. Hum. Toxicol., 25: 13-15.

Doumas, B.T.; W.Watson and H.G. Biggs (1971). A method determination of plasma albumin. Clin . Chemists Acya, 31:87.

Duncan, D.B.(1955). Maltiple range and multiple F-test . Biometrics,11: 1- 42 Elvebach , I.R. ( 1970 ) Method of calcium determination in foods and feed J.Am . MED. Ass., 211- 69

Erwin ,E.S ; G.J. Marcoand and H.Emery (1961).Volatile fatty acids analysis of blood and rumen fluid by gas chromatography., J.Dairy Sci.,44:1768.

Fakete, S.R.(1987). The new system for the evaluation of potato energy. proceeding.1 stNorth.American congress-Oct.10-13,Por.Hand U.S.A.

Gull, S.D.; F.M. Isenberg and H.H.Bryan (1970).Alkaloid toxicology of Solanum-tuberosum. Hort. Science,5: 316.

Hansen,A.A.(1985). Two fatal cases of potato poisoning.Science,61:340 341.Harinder P., H.P.S. Makkar and K.M.Becker,( 2008). increase synthesis of protein from urea supplemented during silage making. Eur.J.Lipid Sci.Technol.111:773-787.

Hoek ,A.E . ; A.G. Lemmens;J. W. M. A. Mullink and A.C.Beynen.(1988) .Influence of dietary calcium:phosphorus ratio on mineral excretion and nephrocalcinosis in female rats. J. of Nutiration .118: pp.1210-1216.

Jadhav, S . J ; R . P . Sharma, and D.K . Salunkhe (1981). Naturally occurring toxic alkaloids in foods. Crit. Rev.Toxicol., $9: 21-104$.

Khalifa , H.A.A.( 1972 ). Effect of low of coarse roughage supplement on the rumen fermentation of sheep . Sudan .J.Vet. Sci. Anim. Husb. , $13: 11$.

Kurihara , Y. ; J.M. Eadie ; P.N.Hobson and S.O. Mann (1988)Relationship between bacteria and cillate protozoa in sheep rumen.j. Gen.Microbial, 51: 267-278 .

Ling, E.R.(1963).Text Book of Dairy Chemistry, Vol.11. Practical Champ man and Hill, London .3 rd Ed.

Linne, J.J. and K.M.Ringsrud (1992). Basic Techniques in clinical Laboratory Science .3므 Ed., Mosby year book.

Mann,S.O.(1968).An improved methods for determining the cellulolytic activity in anerobic bacteria. J. Appl. Microbial ,7:231-241.

Miller,S.E.and J.M.Weller (1971).Textbook of Clinical Pathology. 8hㅡㄹ Ed. The Williams and Wikins Co., Baltimore Scientific Book. Agency. Calcutta. 
Mohammed,A.H.;k.Ibrahim and H.El-Amary(2003).Laincorceration aromatic plants by-products in rumenant diets.rumen fermentation and performance Egyptian J. Nutrition and feeds 7:186 - 197.

Monnet, L.(1963). Determination uf bilirubin Animal Biol. Clin ., 21: 717.

Morris, S.C. and T.H.Lee (1984). The toxicity and teratogenicity mutagens. Mutat. Res., 89: 95 - 136.

Murdoch,J.(1992).Making and feeding silage.Farming Press Books, LTD, Lond.

Nour, A. M. ; A .E.Tag El -Den ; S.M. Zahran and M.H . Ahmed (1989) . Effect of feeding Agro - industrial by - products on total and differential protozoal counts in the rumen .Third Egyptian - British Conference on Animals Products . Alexandria, 7-10 October, $91-101$.

NRC (1981).Nutrient Requirements of Domestic Animals. Nutrient Requaierments of Goats. National Research Council, Washington, D.C. USA of Official Analytical Chemists, Washington, D.C.,USA

Parfitt,D.E.; Peloquine; S.J.and N.A.Jorgensen (1982).The nutritional value of pressed potato vine silage American Potato Journal, 59:415-423.

Patil, B.C. ; R.P. Sharma ; D.K. Salunke and K. Salunkhe (1972).Evaluation of TGA toxicity. Food Cosmet. Toxicol., 10: 395 - 398.

Patton,C.J.and B.C.Crouch (1977).Spectrophotometeric and kinetics investigation of the berthelot reaction for the determination of ammonia. Anal. Chem., 49: 464 - 469.

Pollman,D.S.and D.M.Danielson(1980).Enhancement effect to thehumoralimmune response on blood cells. Potato Journal,59:415 - 423.

Renwick, J.H.; W.D.B.Claringbold ; M.E. Earthy ; J.D.Few and A.C.S.Mclean (1984). Neural-tube defects produced in Syrian hamsters by potato glycoalkaloids. Teratology, 30: 371- 381.

Reitman, S. and S.Frankle (1957). Amethod for determination of plasma GOT and GPT. Am. J. Clin. Path., 28: 108.

Robb J.G.; R.C.Labenl ;J.r. Walker and V.Herring, (1994) . Ether extract digestibility of nutrient digestibility by goats fed discarded potato silage and hay .effect of total glycoalkaloids in potato tuber and discarded parts in dairy goats rations. Journal of Dairy Science 57: 443-449.

Saleh, M.R.M.and A.A.Abd El-Aziz(2007).Potato by-products as animal feed On milk production and milk constituents and their effects on performance of Rahmany ewes.J.Agric.Sci.Mansoura Univ.,32:4235-4245.

Saleh,M.R.and A.A.Abd-Elmordy (2008).Potato by-products as animal feed. feed 2- some rumen parameters . J. Agric. Sci. Mansoura Univ., 33(5): 32013210,2008

Saleh, M. R., Abd- Elmordy, Khalifa, E.I. and El-Emam, G.I.(2009). Potato byproducts as animal feed. Effect of total glycoalkaloids on hematology and blood bio-chemical and constituents in small ruminants. Egypt.J. Appl. Sci., Zagazic,Univ., (8A) :13-29.

SAS Institute (2003).SAS/STATR User's Guide: statistics. Ver. 9.1, SAS Institute Inc., Cary, NC, USA.

Schmeider, B. H. and W.P. Flatt (1975). The Evaluation of Feeds throw the Digestibility Experiment.The University of Georgia Press,Athens, $415 p$. 
Schultz, T.A. and E. Schultz (1970). Estimation of rumen microbial nitrogen by three analytical methods. J. Dairy Sci , 53:781.

Sharma, R.P. and D.K Salunkhe (1981).Naturally occurring toxic alkaloids in foods. Crit. Rev.Toxicol., $9: 21-104$.

Sony,V.K.andD.D.Sharma(1982).Enfluence of levels of concentrate feeding on the microbial population in goat rumen Indian.j.Anim.Sci.,52(9):821.

Sultan , B.E. (1995). Studies on the effects of introducing chemically treated roughages in the feeds of farm livestock. M.Sc. Thesis, Fac. of Agric., Mansoura Univ.

Warner, A.C.I.(1964). Production of volatile fatty acids in the rumen, methods of measurements. Nutr. Abst. \& Rev., 34: 339.

Weichselbaum,M.H.(1989).Colorimetric determination of total protein.Anim.J. PATH., 16:40.

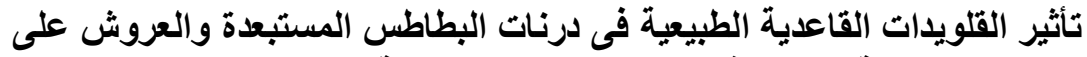

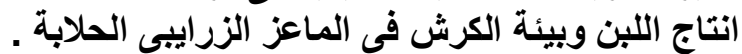
مصطفى راشد محمد صالح

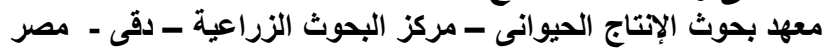

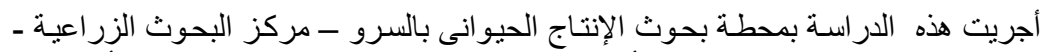

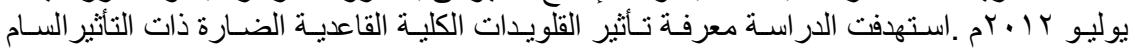

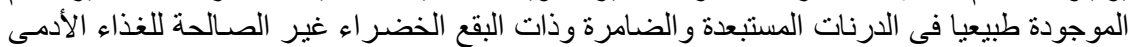

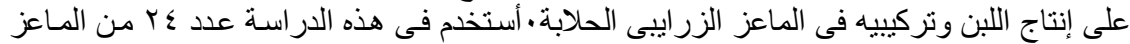

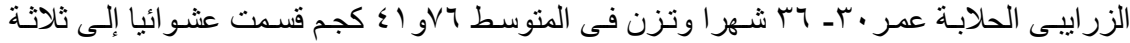

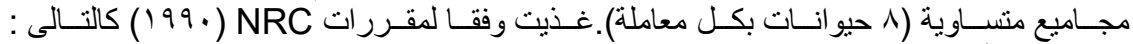

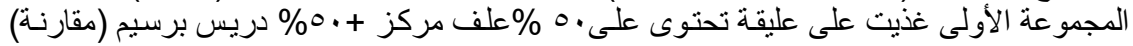

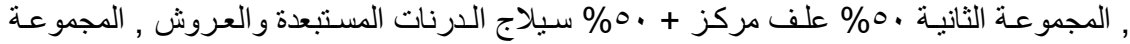
الثالثة غذيث على 0\% علف مركز + • ٪\% دريس العروش وبعض الدرنات المستبعدة والضامرة.

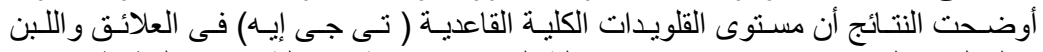

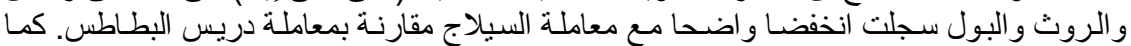

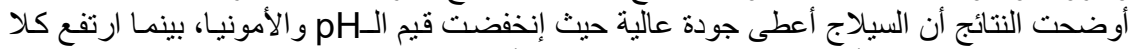

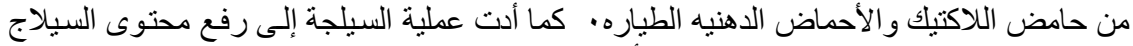

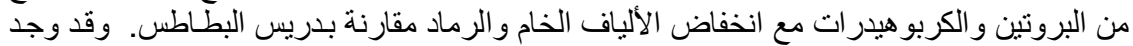

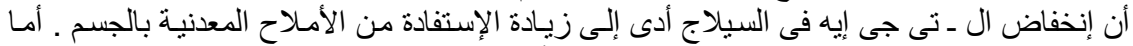

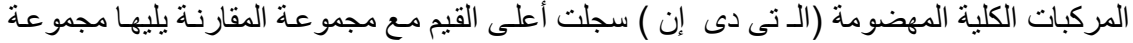

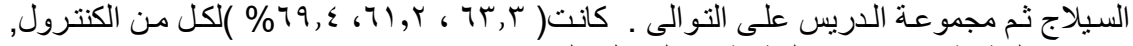

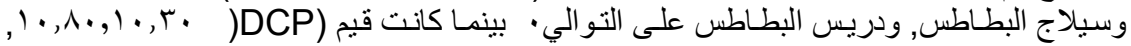

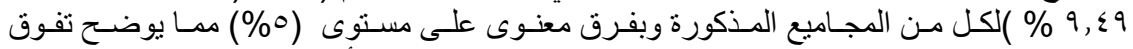

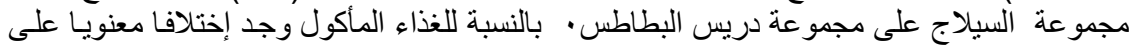

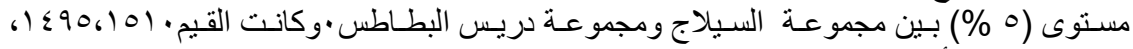

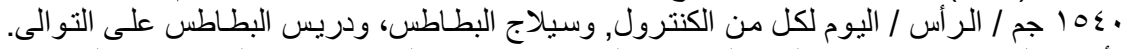

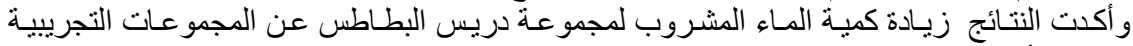

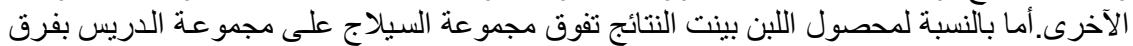

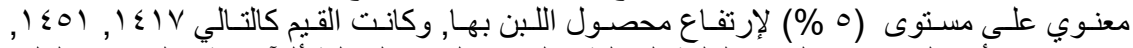

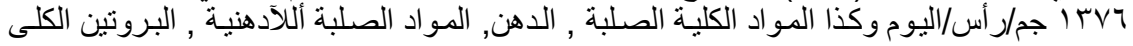




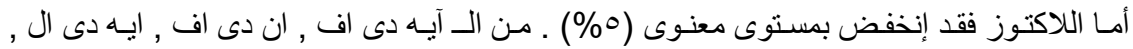

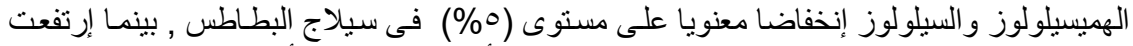

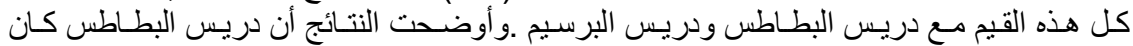

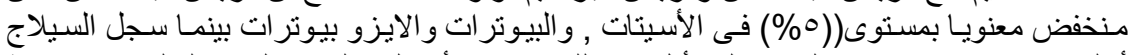

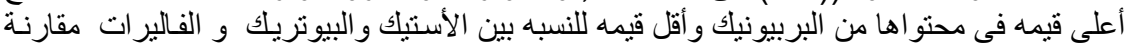

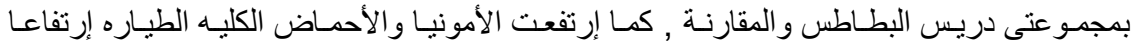

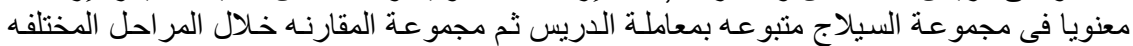

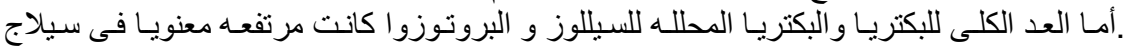

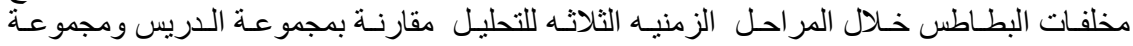

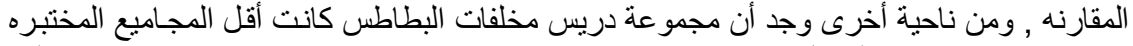

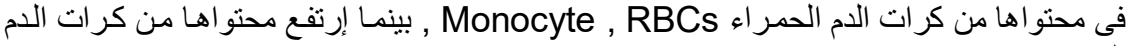
البيضـاء Eiosinophile , Lymphocyte, Neutrophile, WBCs فى حين إنخفضت

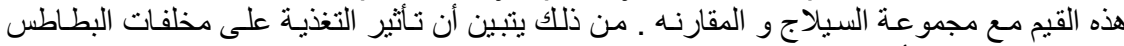

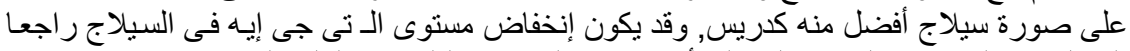

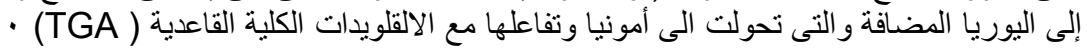

